\title{
PENDEKATAN HERMENEUTIK DALAM MEMAHAMI INTERAKSI NABI SAW. DENGAN OPOSISI DI MADINAH
}

\author{
Dr. Abdul Hakim M.Ag. \\ Institut Agama Islam Negeri (IAIN) Bone \\ abdulhakim@gmail.com
}

\begin{abstract}
Abstrak
Pemahaman terhadap interaksi Nabi saw. dengan Yahudi dan Nasrani, terdapat perbedaan pendapat. Hal ini disebabkan karena adanya pemahaman yang parsial sehingga menghasilkan kesimpulan yang tidak tepat. Oleh karena itu penelitian ini bertujuan mengkaji interaksi Nabi saw. dengan oposisi di Madinah secara utuh dan komprehensif melalui pendekatan hermeneutik. Penelitian ini adalah penelitian kepustakan yang bersifat kualitatif dengan pendekatan teologis-normatif. dan hermeneutik.. Paradigm hermeneutik yang jika dilihat dari segi bentuknya terdiri dari hermeneutika analitis, psikososial dan ontologis. ${ }^{1}$ Khusus dalam memahami teks dalam penelitian seperti ini (hadis-hadis interaksi), maka hermeneutik psiko-sosial merupakan jenis yang memadai. Berdasarkan hal ini maka diproleh hasil sebagai berikut bahwa dengan pemahaman yang utuh melalui kontekstualisasi pendekatan teologis/normatif dan hermeneutik, maka dengan sendirinya teori yang dikembangkan oleh Hannah Rahman akan terbantahkan. Kekeliruan yang dilakukan oleh Hannah Rahman karena berangkat dari teori konflik Karl Marx yang dikembangkan oleh Vilfredo Pareto dan Lewis Coser. Kekeliruan ini dapat terbantah melalui Paradigma Naturalistik atau biasa disebut paradigma defenisi sosial. Paradigma ini dipelopori oleh Max Weber. Ia mengartikan sosiologi sebagai studi tentang tindakan sosial yang "penuh arti" antar hubungan sosial. Tindakan sosial adalah tindakan individu sepanjang tindakannya tersebut mempunyai makna subyektif bagi dirinya dan diarahkan bagi tindakan orang lain. Dengan demikian, melalui pendekatan hermeneutik psiko-sosial tindakan-tindakan nabi terhadap oposisi Madinah dapat dipahami dengan benar.
\end{abstract}

Kata Kunci: Hermeneutik, Nabi, Oposisi, Madinah.

\footnotetext{
${ }^{1}$ Roy. J. Howard, Three Faces of Hermeneutics: An Introduction to Current Teories of Understanding, diterjemahkan oleh Kusmana dan M.S. Nasrullah dengan Judul: Pengantar atas TeoriTeori Pemahaman Kontemporer. Hermeneutika: Wacana Analitik, Psikososial dan Ontologis, h. 145.
} 


\begin{abstract}
Understanding of the interaction of the Holy Prophet. with Jews and Christians, there are differences of opinion. This is due to a partial understanding that results in inaccurate conclusions. Therefore this study aims to examine the interaction of the Holy Prophet. with the opposition in Medina as a whole and comprehensively through the hermeneutic approach. This research is a qualitative library research with theological-normative approach. and hermeneutics .. The hermeneutic paradigm which when viewed in terms of form consists of analytical, psychosocial and ontological hermeneutics. Specifically in understanding texts in research such as these (interaction traditions), psycho-social hermeneutics is an adequate type. Based on this, the following results were obtained that with a complete understanding through the contextualization of theological / normative and hermeneutic approaches, the theory developed by Hannah Rahman would naturally be refuted. The mistake made by Hannah Rahman because it departed from the Karl Marx conflict theory developed by Vilfredo Pareto and Lewis Coser. This mistake can be refuted through the Naturalistic Paradigm or commonly called the social definition paradigm. This paradigm was pioneered by Max Weber. He defines sociology as the study of "meaningful" social actions between social relations. Social actions are individual actions as long as their actions have a subjective meaning for themselves and are directed towards the actions of others. Thus, through the psycho-social hermeneutic approach the actions of the Prophet against the opposition of Medina can be understood correctly.
\end{abstract}

Keywords: Hermeneutics, Prophets, Opposition, Medina.

\title{
PENDAHULUAN
}

Ketika Rasululllah saw. memulai dakwahnya di Mekah perlawanan terhadapnya berasal dari golongan Quraisy yang menyembah berhala dan menggantungkan kehidupan ekonominya pada tempat-tempat suci. Suku Quraisy yang ada di Mekah memandang adanya keterkaitan antara ajaran yang dibawakan oleh Muhammad dengan masyarakat, sehingga mereka melakukan penyikasaan dan pemboikotan terhadap umat Islam. Sehingga selama kurang lebih 13 tahun berdakwah tidak memperoleh hasil yang maksimal.

Sementara itu, di pihak lain situasi Madinah berbeda dengan Mekah. Madinah senantiasa mengalami perubahan sosial yang meninggalkan bentuk kemasyarakatan yang absolut. Kehidupan sosial Madinah secara berangsur-angsur diwarnai oleh unsur kedekatan ruang dari pada kekerabatan. Penduduk Madinah yang memiliki sejumlah penduduk yang beragama Yahudi, Nasrani dan sebahagian telah memeluk Islam sehingga sebahagian besar penduduknya lebih simpatik terhadap monoteisme. Dengan demikian, setelah berlangsung beberapa kali negosiasi akhirnya Nabi 
Muhammmad saw. diundang untuk menyelesaikan kemelut antara kaum Aus dan Khazraj. Kemudian selanjutnya diminta untu hijrah ke Madinah setelah melalui perjanjian Aqabah. ${ }^{2}$

Sejak Rasulullah saw. menetap di Madinah, ia mencurahkan perhatian pada masyarakatnya. Dasar-dasar yang sangat diperlukan dalam menjalankan risalahnya yaitu memperkokoh hubungan umat Islam dengan Tuhannya melalui pembangunan mesjid, memperkokoh hubungan antar umat Islam melalui persaudaraan antara kaum muhajirin dan anshar, serta mengatur hubungan umat Islam dengan non-muslim. ${ }^{3}$

Rasulullah saw memberikan kebebasan beragama bagi masyarakat Madinah dengan tidak memaksa mereka untuk masuk Islam. ${ }^{4}$ Islam menjamin keagamaan dan hukum karena mereka adalah ahl al-dzimmah. Perjanjian yang telah dibuat mencerminkan keinginan kaum muslimin untuk bekerjasama antara semua kelompok untuk menjamin ketentraman di seluruh Madinah. Dalam perjanjian ini juga, kebebasan beragama betul-betul terjamin sehingga di dalamnya tidak tersirat maksud untuk menyerang suatu kelompok atau menindas kaum yang lemah. Bahkan menunjukkan adanya kewajiban semua pihak untuk saling tolong-menolong dan memelihara hubungan baik dalam bermasyarakat.

Dalam perkembangan selanjutnya, di bawah bayang-bayang toleransi beragama, masyarakat Madinah bebas berkreasi dalam bidang budaya dan pemikiran sehingga mereka banyak terpengaruh serta mengadopsi aliran-aliran pemikiran Islam dalam bidang sastra, bahasa, agama, akhlak dan ilmu-ilmu eksperimental.. ${ }^{5}$

Pada mulanya orang Yahudi dianggap akan menyambut kedatangan Islam dengan baik dengan diterimanya isi perjanjian dalam piagam Madinah. Akan tetapi justru seringkali melakukan tindakan yang tidak terpuji dengan mengatasnamakan agama mereka. Padahal secara logika umat Yahudi hendaknya mudah menerima Islam karena Muhammad saw. sangat menghormati Nabi Musa as.

Rasululah saw. dalam berinteraksi dengan dengan oposisi di Madinah kadang lembut dan kadang keras. Pada suatu ketika rasulullah saw. menjalin hubungan yang baik dengan oposisi yang ada di Madinah dengan melarang untuk menzalimi mereka bahkan akan menjadi musuh nabi pada hari kiamat. ${ }^{6}$ Sementara pada sisi yang lain Rasulullah saw. mengancam mereka (oposisi) dengan ancaman akan diusir semuanya dari jazirah arab. ${ }^{7}$ Penelitian ini akan menguraikan tentang adalah bagaimana

\footnotetext{
${ }^{2}$ William E. Phipps, Muhammad and Jesus: A Comparison of the Prophets and Their Teachings, terj. Ilyas Hasan dengan judul, Muhammad \& Isa: Telaah Kritis atas Risalah dan Sosoknya, h. 38-39.

${ }^{3}$ Muhammad Al-Ghaza>li, Fiqh U-Seerah : Understanding the Life of Prophet Muhammad, terj. Kamdani, Sejarah Perjalanan Hidup Muhammmad, (Cet. IV; Yogyakarta: 2005), h. 228.

${ }^{4}$ Lihat QS Al-Ka>firu>n/109: 1-6 dan QS Al-Baqarah/\{2\}: 256.

${ }^{5}$ Ira. M. Lapidus, Sejarah Sosial Umat Islam, terj. Ghufron A. Mas'adi, Jilid 1 dan 2. h. 40.

${ }^{6}$ Imam Abu> Da>ud Sulaima>n Ibn al-Asy'as al-Sijista>ni>, Sunan Abu>Da>ud, Juz. III. (Beirut : Da>r Al-Fikr, t.th.) h. 168.

${ }^{7}$ Ima $>\mathrm{m}$ Abu $>$ Husain Muslim Ibn Hajja>j al-Qusyairi>, S\{ahi>h Muslim, Juz. III (Cet.I; Kairo: Da>r al-Hadi>s\, 1991) h. 1388
} 
memahami hubungan nabi saw. yang sesungguhnya dengan oposisi di Madinah secara utuh dan komprehensif melalui multi pendekatan.

\section{METODOLOGI PENELITIAN}

Agama sebagai fenomena sosial yang bersifat multidimensi, sehingga untuk memahaminya perlu adanya paradigma dan teori berpikir, karena paradigma dan teori yang berbeda akan menghasilkan hasil penelitian yang berbeda pula. Secara garis besar paradigma yang umumnya dipergunakan dalam penelitian sosial-agama adalah paradigma positivistik, paradigma naturalistik paradigma rasionalistik dan paradigma wahyu/teologis. ${ }^{8}$

Mengingat bahwa penelitian ini adalah penelitian tentang hadis di mana ucapan dan perilaku Rasulullah saw. telah terjadi pada masa lalu, maka paradigma penelitian yang dapat dipergunakan dalam hal ini adalah paradigma , naturalistik, rasionalistik dan paradigma teologis/wahyu.

Paradigma sosial akan memandang hadis sebagai fenomena yang dinamis "hidup" sehingga dapat terjadi interaksi dialogis antara manusia dengan hadis. Hadis dan manusia saling berinteraksi yang pada gilirannya terdapat "makna" dan "tindakan penuh arti" dalam memahami agama. Paradigma ini benar-benar menghendaki paradigma yang kontekstual dan fungsional. Pemahaman hadis yang hidup adalah pemahaman yang mampu mendialogkan hadis dengan kehidupan itu sendiri. Dengan demikian teori yang tepat untuk ketiga paradigma tersebut adalah hermeneutika. Oleh karena itu dalam penelitian ini teori yang akan dipakai dalam mengkaji interaksi Nabi saw. dengan oposisi Madinah adalah teori hermeneutik.

Hermeneutika merupakan sebuah metode dalam memahami makna teks sebagai sebuah fenomena sosial budaya. Fungsi metode ini adalah agar tidak terjadi distorsi pesan atau informasi antara teks, penulis teks dan pembaca teks. Secara sederhana hermeneutik dapat dipahami sebagai seni menafsirkan atau memahami, yaitu menjernihkan persoalan mengerti dengan cara menyelidiki setiap detail proses interpretasi. $^{9}$

Menurut jenisnya hermeneutik itu terdiri dari tiga bentuk yaitu hermeneutika analitis, psikososial dan ontologis. ${ }^{10}$ Khusus dalam memahami teks dalam penelitian seperti ini (hadis-hadis interaksi), maka hermeneutik psiko-sosial merupakan jenis yang memadai. ${ }^{11}$

\footnotetext{
${ }^{8}$ Prof. Dr. Imam Suprayogo dan Drs. Tabroni M.Si., Metododlogi Penelitian Sosial Agama, h. 112.

${ }^{9}$ Komaruddin Hidayat, Memahami Bahasa Agama, Sebuah Kajian Hermeneutik, (Jakarta: yayasan Paramadina, 1996), 128-129.

${ }^{10}$ Roy. J. Howard, Three Faces of Hermeneutics: An Introduction to Current Teories of Understanding, diterjemahkan oleh Kusmana dan M.S. Nasrullah dengan Judul: Pengantar atas TeoriTeori Pemahaman Kontemporer. Hermeneutika: Wacana Analitik, Psikososial dan Ontologis, h. 145.

${ }^{11}$ E. Sumaryono, Hermeneutik Sebuah Metode Filsafat, (Yogyakarta: Kanisisus, 1999), h. 3839.
} 


\section{A. INTERAKSI NABI SAW.> DENGAN OPOSISI DI MADINAH}

\section{Interaksi Nabi saw. dengan Oposisi di Madinah Menurut Hannah Rahman}

\section{a. Konflik dengan Bani Qainuqa}

Sumber-sumber yang mengemukakan alasan mengenai konflik bersenjata dengan Bani Qainuqa yang berujung pada pengusiran mereka dari Madinah adalah: Pertama, mereka dianggap cuci tangan dan tidak bersimpatik atas kemenangan umat Islam dalam Perang Badar, bahkan mereka meremehkan kemenangan yang diperoleh umat Islam dengan sebaliknya bersimpatik kepada kaum musyrikin dengan jalan mengirimkan syair. Kedua, peristiwa di mana seorang wanita Arab yang kebetulan beragama Islam membawa perhiasannya ke tempat perdagangan Yahudi Bani Qainuqa untuk menyepuh perhiasannya. Ketika ia sedang menunggu, tiba-tiba datang orang-orang Yahudi berkerumun mengelilinginya dan memintanya untuk membuka penutup mukanya tetapi ditolaknya. Kemudian secara diam-diam tukang sepuh emas tersebut menyangkutkan pakaian wanita tersebut dan ketika berdiri maka terbukalah auratnya pada bagian belakang sehingga orang-orang Yahudi menertawakannya. Wanita tersebut menjerit minta pertolongan sehingga datanglah seorang muslim yang menyerang tukang sepuh tersebut dan membunuhnya. Peristwa tersebut memicu terjadinya perang kelompok antara keduanya. ${ }^{12}$

Menurut Hannah kedua hal tersebut di atas tidak dapat dijadikan alasan untuk mengusir Bani Qainuqa dari Madinah dengan alasan: Pertama, sehubungan dengan status mereka sebagai bagian dari ummah adalah bahwasanya mereka akan mendapatkan hak-hak, tugas-tugas dan kewajiban yang sama dalam mempertahankan Madinah. Akan tetapi mereka tidak diikutkan dalam perang Badar sehingga wajar jika mereka tidak bergembira atas kemenangan tersebut. Kedua, peristiwa yang menimpa seorang wanita Arab yang kebetulan beragama Islam adalah suatu kejadian biasa yang sangat khas bagi masyarakat Arab jika orang banyak bertemu sering terjadi percekcokan dan perkelahian yang tak terhindarkan. Peristiwa sosial ini kemudian diberi bobot yang besar dari peristiwa sosial dan ekonomi yang biasa menjadi sengketa keagamaan yang hanya karena kebetulan yang mendapatkan pelecehan adalah seorang yang beragama Islam. ${ }^{13}$

Lebih lanjut Hannah mengatakan bahwa alasan mengapa Nabi saw. mengusir Bani Qainuqa dari Madinah adalah karena ia ingin menguasai kedudukan yang paling menguntungkan di tengah-tengah hubungan antar suku yang ada di Madinah dan sekitarnya yaitu pasar. Kekuasaan atas pasar bukan hanya akan memberikan keuntungan ekonomi tetapi juga politik sehingga wajar jika Nabi saw. menginginkan hal tersebut. Akan tetapi karena persaingan dengan orang Yahudi dan sekutunya yang

\footnotetext{
${ }^{12}$ Muhammad Al-Gazali, Fiqh U-Seerah: Understanding the Life of Prophet Muhammad, diterjemahkan oleh Kamdani, dengan Judul: Sejarah Perjalan Hidup Muhammad, h. 312-314.

${ }^{13}$ Hannah Rahman, "Pertentangan Antara Nabi dan Golongan Oposisi di Madinah" dalam : Pandangan Barat Terhadap Islam Lama, diterjemahkan oleh Sukarsih, Seri 4. (Jakarta: INIS, 1989),h. 66-67.
} 
memiliki kekuatan besar di Madinah pada awal ketika Nabi saw. berada di Madinah maka ia mengurungkan niatnya sampai datang waktu yang tepat. ${ }^{14}$

\section{b. Konflik dengan Bani Nadir}

Sumber-sumber mengenai pengusiran Bani Nadir dari Madinah menyebutkan ada beberapa alasan. Ada yang menghubungkannya dengan akibat dari ekspedisi Bir Ma'unah dan ada juga yang menghubungkannya dengan perang Uhud, di mana mereka dituduh menghasut orang-orang kafir Quraisy dan memberitahukan kepada mereka jalan-jalan ke tempat-tempat di perbatasan yang dijaga dijaga ketat. Namun asumsi yang paling kuat adalah bahwa ketika Rasulullah saw. mendatangi beberapa orang Yahudi yang terikat dalam perjanjian damai untuk minta bantuan dalam membayar ganti rugi atas dua jenazah korban Amir bin Umayah yang salah membunuh orang.

Menurut Hannah para ahli sejarah mempertanyakan hak Nabi saw. untuk meminta bantuan kepada Bani Nadir dalam membayar uang diyat atas pembunuhan yang dilakukan seseorang yang sama sekali asing bagi Bani Nadir. Sedangkan menurut perjanjian antara Nabi saw. dengan orang Yahudi di Madinah adalah bahwa masing-masing suku dan kaum bertanggung-jawab atas perbuatan anggotanya dan membayar uang diyatnya sendiri. ${ }^{15}$

Selanjutnya Hannah mengatakan bahwa sebenarnya Bani Nadir telah sepakat untuk membayar uang diyat tersebut. Akan tetapi kemudian mereka dituduh merencanakan pembunuhan terhadap Nabi saw. yang sementara berunding dengan mereka. Hal ini tidak dapat dijadikan alasan dalam pengusiran bani Nadir karena kenyataannya Nabi saw. mengusir mereka setelah pengepungan yang menjemukan dan membakar pohon-pohon kurma yang menjadi sandaran mereka. Kemudian jika dihubungkan dengan dengan perang Uhud, agaknya sumber yang dapat dijadikan untuk memahaminya kurang memadai karena kalau seandainya ini benar, lalu kenapa Nabi saw. lalu meminta bantuan kepada mereka untuk membayar uang diyat. Perubahan sikap Nabi saw. yang mendadak inilah yang tidak mendapatkan penjelasan dalam kitab-kitab sejarah. ${ }^{16}$ Sebagai legitimasi dalam pengusiran Bani Nadir dari Madinah maka para sejarawan muslim menghubungkannya dengan firman Allah dalam QS. Al-Hasyr/59: $2 .^{17}$

\section{c. Konflik dengan Bani Quraizah}

Suku Yahudi terakhir yang tinggal di Madinah adalah Bani Quraizah. Pengusiran mereka dari Madinah disebabkan karena mereka melakukan kejahatan atau penghianatan terhadap kesatuan ummah. Mereka bersekongkol dengan Bani

\footnotetext{
${ }^{14}$ Hannah Rahman, "Pertentangan Antara Nabi dan Golongan Oposisi di Madinah” dalam : Pandangan Barat Terhadap Islam Lama, h. 68.

${ }^{15}$ Hannah Rahman, "Pertentangan Antara Nabi dan Golongan Oposisi di Madinah” dalam : Pandangan Barat Terhadap Islam Lama, h. 71-72.

${ }^{16}$ Hannah Rahman, "Pertentangan Antara Nabi dan Golongan Oposisi di Madinah” dalam : Pandangan Barat Terhadap Islam Lama, h. 73.

${ }^{17}$ Departemen Agama RI., Al-Qur'an dan Terjemahnya, h.
} 
Nadir, orang-orang Mekah dan Bani Gatafan untuk melakukan serangan Gabungan terhadap Nabi saw.. Orang-orang Mekah dan Bani Gatafan bermaksud menyerang Madinah dari arah Timur dan Utara, sementara Bani Quraizah yang berada di Madinah akan menyerang dari dalam. Namun demikian ternyata sekutu mereka lemah sehingga orang Mekah dan Bani Gatafan mengundurkan diri setelah pengepungan yang sia-sia. Setelah itu maka Nabi saw. merapatkan barisan orangorang Madinah untuk melawan dan menumpas Bani Quraizah.. ${ }^{18}$

Menurut Hannah seandainya benar-benar orang Islam menganggap bahwa hukuman yang diberikan kepada Bani Quraizah terlalu berat lalu kenapa mereka lebih menonjolkan wahyu ilahi sebagai pembenaran dari tindakan mereka dari pada fakta yang ada. Sebagimana disebutkan bahwa Abu Lubabah yang menjadi pelindung Bani Quraizah telah mewakili mereka dalam menyampaikan penyesalan atas tindakan mereka dalam melakukan penghianatan terhadap ummah. Ia melakukan tindakan dengan jalan mengikat tubuhnya di tiang Mesjid dan bersumpah tidak akan melepaskan dirinya dan tidak mau makan dan minum dengan harapan agar Nabi saw. memberikan pegampunan atas mereka. Ia berusaha mempengaruhi Nabi saw. agar bersikap toleran terhadap kaum yang dilindunginya (Bani Quraizah). ${ }^{19}$

Demikian juga ketika mereka berada dalam kepungan pasukan umat Islam yang berlangsung selama dua puluh lima hari, mereka bersedia untuk tunduk dan menyerah dengan bersedia tunduk kepada keputusan Sa'ad bin Muaz. Lalu mereka keluar dari benteng dan kemudian digiring ke tempat penahanan menunggu kedatangan Sa'ad bin Muaz. Mereka berharap ia dapat menjadi penengah antara Nabi saw. dan Bani Quraizah. (sebagaimana diketahui bahwa Sa'ad adalah pemimpin Bani Aus yang pernah bersekutu dengan Bani Quraizah). Mereka berharap akan mendapatkan pengampunan melalui manfaat dari hubungan mereka pada masa lampau. Akan tetapi yang terjadi adalah sangat bertolak belakang dengan apa yang mereka harapkan. Meskipun berada di tengah-tengah orang Yahudi yang memohon belas kasihan kepadanya namun ternyata Sa'ad memutuskan untuk menghukum mereka seberat-beratnya. ${ }^{20}$

Meskipun orang-orang Yahudi tersebut memohon kepada Sa'ad bin Muaz namun dengan tegas ia memutuskan bahwa: "Semua laki-laki Yahudi yang ikut berkhianat dibunuh, keluarga mereka ditahan sebagai budak dan semua harta kekayaan mereka disita dan dibagikan kepada kaum muslimin." Keputusan Sa'ad yang tegas ini kemudian disambut baik dan dibenarkan oleh Rasulullah saw. ${ }^{21}$

\footnotetext{
${ }^{18}$ Hannah Rahman, "Pertentangan Antara Nabi dan Golongan Oposisi di Madinah” dalam : Pandangan Barat Terhadap Islam Lama, h. 74.

${ }^{19}$ Hannah Rahman, "Pertentangan Antara Nabi dan Golongan Oposisi di Madinah” dalam : Pandangan Barat Terhadap Islam Lama, h. 74.

${ }^{20}$ Hannah Rahman, "Pertentangan Antara Nabi dan Golongan Oposisi di Madinah” dalam : Pandangan Barat Terhadap Islam Lama, h. 75.

${ }^{21}$ Hannah Rahman, "Pertentangan Antara Nabi dan Golongan Oposisi di Madinah” dalam : Pandangan Barat Terhadap Islam Lama, h. 74. Muhammad Al-Gazali, Fiqh U-Seerah:
} 


\section{Bantahan terhadap Pandangan Hannah Rahman}

Tesis yang dikembangkan oleh Hannah Rahman (Haifa) adalah keliru karena berangkat dari paradigma yang keliru. Kekeliruan yang dilakukan oleh Hannah karena ia berangkat dari paradigma positivistik (paradigma fakta sosial) yang menurut Emile Durkhein bahwa realitas sosial memiliki daya paksa untuk menentukan sesuatu. ${ }^{22}$ Demikian juga teori yang dipakai dalam mengkaji oposisi pada zaman Nabi saw. adalah teori konfliknya Karl Marx yang kemudian dikembangkan oleh Vilfredo Pareto dan Lewis Coser.

Vilfredo Pareto mengatakan bahwa pergolakan politik dunia sebagai akibat dari pertentangan antara dua tipe individu yaitu (singa, penguasa, penindas) dan (kancil atau yang dikuasai). Sementara Lewis Coser mengatakan bahwa konflik adalah perselisihan mengenai nilai atau tuntutan yang berkenaan dengan status, kekuasaan dan sumber kekayaan. Pihak yang berselisih tidak hanya berusaha memperoleh barang tetapi juga memojokkan, merugikan bahkan dapat menghancurkan lawan mereka. ${ }^{23}$

Konflik dalam masyarakat akan muncul dengan sendirinya apabila pranata atau struktur sosial yang ada dianggap tidak memadai lagi. Struktur sosial yang lama perlu diganti atau direformasi dalam rangka menciptakan tatanan dan keseimbangan kehidupan yang baru. Oleh karena itu menurut teori ini konflik sangat dibutuhkan agar masyarakat dan negara tidak lenyap. Dalam tatanan masyarakat terdapat dua kelompok yaitu; yang menguasai dan yang dikuasai baik dalam hal politik maupun ekonomi. Dua kelompok inilah yang senantiasa melakukan pergumulan yang akan menciptakan dalam menciptakan perubahan dan kemajuan.

Berikut ini akan dikemukan beberapa contoh pernyataan Hannah yang menunjukkan bahwa ia mempergunakan teori konflik sebagai berikut:

\section{a. Konflik dengan Bani> Qainuqa.}

Menurut Hannah latar belakang sehingga Nabi saw. mengusir Bani Qainuqa dari Madinah adalah karena Bani Qainuqa menguasai kedudukan yang paling menguntungkan (pasar) di tengah-tengah hubungan antara suku yang ada di Madinah. Pasar merupakan tempat pertemuan umum bagi segala macam hubungan sosial apapun dapat berlangsung. Kekuasaan akan pasar tidak hanya memberikan keuntungan ekonomi akan tetapi juga kekuasaan politik. Oleh karena itu ketika Muhammad saw. tiba di Madinah ia berusaha membangun pasarnya sendiri. Akan tetapi ia harus bersaing dengan orang-orang Yahudi (Ka'ab Ibn Asyraf) yang kebetulan lebih unggul daripadanya sehingga ia mengurungkan niatnya untuk

Understanding the Life of Prophet Muhammad, diterjemahkan oleh Kamdani, dengan Judul: Sejarah Perjalan Hidup Muhammad, h. 408-409.

${ }^{22}$ Imam Suprayogo dan Tobroni, Metodologi Penelitian Sosial Agama, h. 84.

${ }^{23}$ Imam Suprayogo dan Tobroni, Metodologi Penelitiian Sosial Agama, h. 98-99. 
menguasai pasar. Oleh karena itu Muhammad saw. menunggu kesempatan yang dapat melemahkan saingannya (Bani Qainuqa). ${ }^{24}$

Kesempatan tersebut secara tak terduga tiba-tiba datang dan Nabi saw. yang memiliki bakat politik, mempergunakan kesempatan tersebut. Kesempatan yang dimaksud adalah secara kebetulan menurut riwayat bahwa di suatu pasar terjadi peristiwa khas bagi masyarakat Arab bila orang banyak bertemu yaitu percekcokan dan perkelahian yang tidak dapat dihindarkan. Peristiwa ini bermula dari seorang wanita yang sedang menawarkan barang dagangannya di dekat penjual/pandai emas. $^{25}$ Lalu si penjual emas tersebut menggoda wanita tersebut yang kebetulan beragama Islam. Suasana lebih menjadi panas ketika penjual emas tersebut dikipasi oleh teman-temannya sehigga ia bertingkah laku melampaui batas sopan santun (ujung pakaian perempuan tersebut disangkutkan sehingga apabila berdiri maka pakaiannya akan terbuka) yang walaupun dalam pikirannya untuk memancing tawa orang banyak. Selanjutnya perempuan tersebut ditolong oleh laki-laki muslim dengan membunuh padai/pedagang emas tersebut yang akibatnya harus di bayar dengan nyawanya sendiri karena dibunuh oleh teman Yahudi tersebut. Peristiwa tersebut kemudian berkembang sehingga terjadilah pertikaian yang besar antara kelompok Islam dan kelompok Yahudi selama kurang lebih lima belas hari. Menurut Hannah sengketa sosial yang biasa ini menjadi sengketa keagamaan. ${ }^{26}$

Kemudian setelah itu mereka menyerah dan bersedia menerima hukuman dari Nabi saw. sebagai pemimpin ummah. Kemudian diutuslah Abdulla $>$ h Ibn Ubay pemimpin mereka untuk membujuk Nabi saw. untuk memperlakukan dengan baik orang-orang Yahudi tersebut. Ketika perkara ini di bawa ke hadapan Nabi saw. sebagai penguasa tertinggi di dalam Ummah maka ia mempergunakan kesempatan ini untuk menciptakan keadaan yang menguntungkan pihaknya. Berkat wawasan dan kecerdasan diplomasinya sehingga Nabi saw. berhasil mengusir bani Qaiunuqa. Dengan demikian maka Nabi saw. dapat melaksanakan ambisinya menguasai pasar. Menurut sebuah versi bahwa ketika terjadi perundingan 'Abdullah Ibn Ubaiy banyak mengalami penghinaan. Contohnya adalah ketika ia sedang mengintai Nabi saw. ia dilihat oleh Uwaim Ibn $\mathrm{Sa}^{\prime} \mathrm{i}>$ dah lalu ditampar di depan orang banyak. Penghinaan seperti ini bagi masyarakat Arab adalah sesuatu yang sangat serius. ${ }^{27}$

\footnotetext{
${ }^{24}$ Hannah Rahman, "Pertentangan Antara Nabi dan Golongan Oposisi di Madinah” dalam : Pandangan Barat Terhadap Islam Lama, diterjemahkan oleh Sukarsih, Seri 4. (Jakarta: INIS, 1989), h. 29.

${ }^{25}$ Versi lain mengatakan bahwa wanita muslim tersebut membawa perhiasannya ke seorang tukang sepuh tempat perdagangan Bani Qainuqa. Kemudian ketika ia menunggu tukang sepuh itu menyelesaikan pekerjaannnya terjadilah peristiwa tersebut. Muhammad Al-Gazali, Sejarah Perjalan Hidup Muhammad, h. 314.

${ }^{26}$ Hannah Rahman, "Pertentangan Antara Nabi dan Golongan Oposisi di Madinah" dalam : Pandangan Barat Terhadap Islam Lama, h. 68.

${ }^{27}$ Hannah Rahman, "Pertentangan Antara Nabi dan Golongan Oposisi di Madinah" dalam : Pandangan Barat Terhadap Islam Lama, h. 69.
} 
Kekeliruan tesis yang dikemukakan oleh Hannah adalah karena berangkat dari teori konflik Karl Max. Teori ini memandang bahwa dalam suatu perselisihan mengenai nilai atau tuntutan yang berkenaan dengan status, kekuasaan dan sumber kekayaan, pihak yang berselisih tidak hanya berusaha memperoleh barang tetapi juga memojokkan, merugikan bahkan dapat menghancurkan lawan mereka. Demikian juga teori yang mengatakan bahwa pergolakan politik dunia sebagai akibat dari pertentangan antara dua tipe individu yaitu (singa, penguasa, penindas) dan (kancil atau yang dikuasai).

Teori ini tidak dapat dipakai dalam memotret kehidupan Nabi saw. di Madinah dengan alasan. Pertama, Nabi saw. hijrah ke Madinah untuk menjadi pemimpin di sana bukan atas inisiatif sendiri dan bukan untuk menguasai orangorang Madinah, akan tetapi atas permintaan kaum Aus dan Khazraj untuk mendamaikan mereka yang sudah lama berselisih. Kedua, kedatangan Nabi saw. di Madinah tidak terbukti untuk menumpas orang-orang yang tidak sepaham dengan mereka karena justru Nabi saw. membangun koalisi politik dengan mereka melalui piagam Madinah. Bahkan dalam hadis interaksi yang telah dikemukakan di atas menunjukkan adanya kerja sama antara semua golongan yang ada di Madinah termasuk oposisi. Contohnya adalah dalam interaksi masalah politik yang telah dikemukakan di atas justru memberikan perlindungan kepada non muslim dan mengancam orang yang menzalimi mereka. Ketiga, Pernyataan Hannah bahwa Nabi saw. ingin membangun dan menguasai pasar adalah tidak benar karena terbukti bahwa ia melakukan kerja sama dengan orang-orang Yahudi seperti yang telah disebutkan dalam hadis interaksi di atas seperti kerjasama dalam pertanian dan jualbeli. Keempat, tidak ada riwayat yang menyebutkan bahwa ketika Nabi saw. sudah menguasai Madinah menjadi orang yang menguasai/mengendalikan pasar berdasarkan kehendaknya.

Selanjutnya mengenai pernyataan Hannah yang mengatakan bahwa peristiwa penghinaan terhadap perempuan muslim di pasar adalah peristiwa sosial biasa yang berubah menjadi sentimen agama yang berujung pada diusirnya Bani Qainuqa dari Madinah, adalah keliru dengan alasan: Pertama, Hannah tidak melihat rangkaian peristiwa sebelumnya, di mana ketika Nabi saw. menghadapi kaum musyrikin dalam perang Badar justru mereka berpihak pada kaum musyrik tersebut, bahkan melancarkan propaganda anti Islam. Kedua, setelah umat Islam bergembira menyambut kemenangan dalam perang badar justru orang-orang Yahudi mengejek dengan mengatakan bahwa : “ janganlah bangga dengan kemenangan dari orang yang tidak mengetahui peperangan, seandainya kami yang anda hadapi niscaya kamu akan mengetahui siapa sebenarnya kami". ${ }^{28}$ Ketiga, pelecehan terhadap seorang perempuan tidak bisa dipandang sebagai peristiwa sosial biasa karena ini menyangkut persoalan prinsip dalam agama yang harus membela terhadap kaum yang lemah (perempuan).

\footnotetext{
${ }^{28}$ Muhammad Al-Gazali, Sejarah Perjalan Hidup Muhammad, h. 313.
} 


\section{b. Konflik dengan Bani> Na>dir}

Menurut Hannah sumber-sumber yang menjadi alasan pengusiran Bani $\mathrm{Na}>$ dir, sebagian besar dihubungkan dengan peristiwa $\mathrm{Bi}>r$ Mau>nah dan ada juga yang menghubungkannya dengan perang Uhud. Pendapat lain mengatakan bahwa karena mereka bertanggung jawab atas perbuatan Ka'ab Ibn Asyraf yang banyak memusuhi Nabi saw. melalui kerja sama dengan kaum Quraisy Mekah dan melalui syair yang berisi profokasi dan rayuan kepada wanita muslimah. ${ }^{29}$

Sumber lain menyebutkan bahwa pengusiran Bani Nadir disebabkan karena mereka dituduh menghasut kaum kafir Quraisy untuk menyerang Nabi saw. dan memberitahukan jalan-jalan ke tempat-tempat perbatasan yang dijaga, sehingga dianggap melanggar parjanjian dengan Nabi. Akan tetapi puncaknya adalah ketika suatu hari Rasulullah mendatangi beberapa orang Yahudi untuk minta bantuan membayar ganti rugi atas dua jenazah korban pembunuhan yang dilakukan oleh 'Amir Ibn Umayyah yang salah membunuh orang. ${ }^{30}$

Menurut Hannah, tanpa mengindahkan latar belakang tersebut, yang jelasnya Nabi saw. telah mengusir Bani> Na>dir dari Madinah setelah dipaksa keluar dari kemah mereka setelah pengepungan yang menjemukan. Nabi saw. memerintahkan untuk membakar pohon-pohon kurma yang menjadi sandaran hidup mereka, rumahrumah mereka dibakar dan diambil sebagian harta mereka sebagai harta rampasan perang lalu dibagikan kepada kaum muhajirin. ${ }^{31}$

Tesis yang dikemukakan oleh Hanah tersebut di atas kurang tepat karena ia lebih menonjolkan bagaimana ketika Nabi saw. mengusir Bani> Na>dir dari Madinah tanpa memperhatikan rangkaian peristiwa yang dialami oleh Nabi saw. sebelum pengusiran tersebut. Hal-hal tersebut antara lain adalah: Pertama, Nabi saw. baru saja mengalami beberapa peristiwa yang membuatnya sedih dan memiliki beban psikologis yang membuatnya semakin hati-hati dalam bertindak yaitu; kekalahan dalam perang uhud, serangan dari kelompok-kelompok suku badui dan yang paling menyedihkan adalah peristiwa $b i>r m a ' u>n a h$. Kedua, adanya beberapa kali penghianatan yang dilakukan oleh orang Yahudi baik kelompok maupun pribadi. Ketiga, ketika Nabi saw. meminta bantuan kepada Bani> Na>dir sebagai konsekuensi bagian dari ummah, untuk membatu dalam pembayaran ganti rugi atas kesalahan Amir Ibn Umayyah dalam salah membunuh orang. Justru di tengah penantian akan kesanggupan mereka membayar ganti rugi tersebut, kemudian orang Yahudi yang telah sepakat tadi, dengan diam-diam menemui temannya untuk melakukan pembunuhan kepada Nabi saw. dengan cara melempar batu. Tentu hal ini akan dilakukan oleh siapapun yang merasa jiwanya terancam, apa lagi dari orang-orang

\footnotetext{
${ }^{29}$ Hannah Rahman, "Pertentangan Antara Nabi dan Golongan Oposisi di Madinah" dalam : Pandangan Barat Terhadap Islam Lama, h. 71.

${ }^{30}$ Hannah Rahman, "Pertentangan Antara Nabi dan Golongan Oposisi di Madinah" dalam : Pandangan Barat Terhadap Islam Lama, h. 72.

${ }^{31}$ Hannah Rahman, "Pertentangan Antara Nabi dan Golongan Oposisi di Madinah" dalam : Pandangan Barat Terhadap Islam Lama, h. 73.
} 
yang telah mengikat perjanjian dengannya. Keempat, Nabi saw. tidak berniat mengusir Bani> Na>dir melalui dengan peperangan akan tetapi mereka disuruh meninggalkan Madinah dengan baik-baik dan diberi waktu 10 hari untuk mempersiapkan hal tersebut. ${ }^{32}$

\section{c. Konflik dengan Bani> Quraizah}

Suku Yahudi terakhir yang tinggal di Madinah yang tidak ikut serta menentang secara aktif terhadap Nabi saw. sampai pada tahun ke 5 Hijriah adalah Bani> Quraizah. Nanti setelah tahun tersebut baru mereka melakukan kejahatan terhadap kesatuan ummah. Orang-orang Yahudi menyadari bahwa mereka tidak akan sanggup mengalahkan Islam kalau mereka bergerak sendiri-sendiri dan terpisah. Sehingga mereka berpikir akan tercapai keinginannya jika Islam diserang oleh suatu kekuatan yang terpadu.

Usaha ini dilakukan oleh tokoh-tokoh Yahudi dari Bani> Na>dir yang ada di Khaibar berangkat ke Mekah untuk membangun koalisi dengan orang-orang Mekah, orang orang Badui dari Bani Gatafa $>n$ dan kabilah-kabilah yang dendam terhadap Nabi saw. (Fiza>rah, Murrah dan Sulaim) karena mereka pernah diperangi setelah peristiwa $\mathrm{Bi}>\mathrm{r} \mathrm{Ma}^{\mathrm{u}} \mathrm{u}>$ nah. Demikian juga mereka mengajak Bani Quraizah untuk melakukan serangan gabungan terhadap Nabi saw. Namun koalisi tersebut ternyata gagal karena pasukan kaum muslimin menempuh siasat yang sama sekali belum pernah ditempuh oleh orang Arab kala itu yaitu menggali parit sebagai benteng pertahanan. Di samping siasat tersebut peranan yang paling penting adalah apa yang

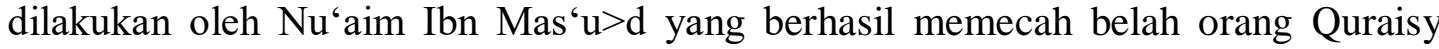
Mekah, Bani Gataf $\} a>n$ dan Bani> Quraizah. Sehingga orang-orang Mekah dan Bani Gat $\}$ afa $>n$ mengundurkan diri dari medang perang. ${ }^{33}$

Setelah peristiwa tersebut lalu Nabi saw. merapatkan barisan orang-orang Madinah untuk melawan dan menumpas Bani Quraizah yang melakukan penghianatan dalam perang $A h z\} a b$. Lamanya pengepungan, kedinginan dan kelaparan pastilah sesutau yang membosankan sehingga Abu> Luba>bah pemimpin mereka berusaha mencari simpati dengan mengikat tubuhnya di depan Mesjid sampai tidak mau makan dan minum agar supaya Nabi saw. bersikap toleran memberikan pengampunan atas mereka. Kemudian selanjutnya atas persetujuan Bani> Quraizah Sa'ad Ibn Mu'a $>\mathrm{zl}$ diangkat sebagai pendamai antara Nabi saw. dengan Bani> Quraizah dengan harapan terjaminnya posisi mereka dengan mendapatkan keputusan yang menguntungkan mengingat bahwa $\mathrm{Sa} a^{\prime} \mathrm{ad} \mathrm{Ibn} \mathrm{Mu}^{\mathrm{a}} \mathrm{a}>\mathrm{z} \backslash$ adalah dulu beragama Yahudi. Akan tetapi justru Sa'ad berpendirian teguh dan tak kenal kompromi

\footnotetext{
${ }^{32}$ Muhammad Al-Gazali, Sejarah Perjalan Hidup Muhammad, h. 363.

${ }^{33}$ Hannah Rahman, "Pertentangan Antara Nabi dan Golongan Oposisi di Madinah" dalam : Pandangan Barat Terhadap Islam Lama, H. 74.
} 
sehingga semua laki-laki Bani> Quraizah yang telah akil-balig dijatuhi hukuman mati. Kaum wanita, anak-anak dan harta kekayaan mereka dirampas dan dijual. ${ }^{34}$

Walaupun kelihatannya hukuman yang diberikan kepada Bani Quraizah tersebut di atas kelihatannya adalah kejam akan tetapi ini dilakukan Nabi saw. bukan karena alasan politik dan ekonomi. Buktinya adalah karena setelah pengusiran seluruh suku-suku Yahudi dari Madinah Nabi saw. tetap bekerja sama/ berbuat baik terhadap orang Yahudi yang tidak melakukan perlawanan atau terikat dalam perjanjian ummah. Hal ini terbukti ketika Rasulullah saw. sudah menguasai Khaibar ia tetap mempekerjakan petani-petani yang ada di Khaibar.

Selanjutnya Hannah mengatakan bahwa literatur-literatur, baik bersumber dari al-Qur'an dan $a s b a>b$ nuzul-nya serta hadis tidak dapat dipakai sebagai sumber terpercaya untuk bahan-bahan dalam membahas oposisi Yahudi di Madinah dan hubungannnya dengan Nabi saw. Karena literatur tersebut dipengaruhi oleh gagasangagasan teologi yang berkembang belakangan setelah waktu yang dimaksud dan lebih cendrung memandang watak keagamaaan dari pada aktifitas orang Yahudi di Madinah pada priode ketika peristiwa itu berlangsung. ${ }^{35}$

Kalaupun literatur-literatur dari hadis maupun Alquran tidak dipercayai oleh Hannah maka sesungguhnya aktifitas orang Yahudi di Madinah jika ditinjau dari faktor ekonomi dan politik pun dapat dibenarkan dengan alasan. Pertama, secara politik antara Nabi saw. dengan seluruh penduduk Madinah termasuk orang-orang Yahudi telah terikat dalam satu perjanjian "ummah" dan Nabi saw. tidak pernah sekalipun melanggar perjanjian tersebut. Tapi justru sebaliknya orang-orang Yahudilah yang paling sering melanggar hal tersebut. Kedua, secara ekonomi Nabi saw. tidak pernah melarang aktivitas ekonomi yang dilakukan oleh orang Yahudi, apalagi berniat untuk menguasai pasar. Jadi sangat keliru jika Hannah mengatakan bahwa Nabi saw. membangun pasarnya sendiri, akan tetapi yang benar adalah Nabi saw. ingin menata tatanan kehidupan dalam bentuk negeri yang aman. Oleh karena itu ia membuat sebuah perjanjian bersama (ummah).

Selanjutnya pernyataan Hannah yang mengatakan bahwa tindakan nabi saw dalam mengusir kaum Yahudi dari Madinah lebih cendrung memandang watak keagamaan, adalah tidak benar karena Nabi saw. tidak pernah memaksakan sesesorang untuk memeluk agama Islam. Bahkan Nabi saw. memberikan kebebasan kepada setiap agama untuk menjalankan agamanya masing-masing. Pernyataan Rasulullah saw. tentang pengusiran orang Yahudi dan Nasrani tidak dapat dikatakan sebagai watak keagamaan akan tetapi lebih kepada adanya penghianatan yang dilakukan oleh mereka dalam melanggar perjanjian bersama. Hadis yang dimaksud adalah sebagai berikut :

\footnotetext{
${ }^{34}$ Hannah Rahman, "Pertentangan Antara Nabi dan Golongan Oposisi di Madinah" dalam : Pandangan Barat Terhadap Islam Lama, h. 75.

${ }^{35}$ Hannah Rahman, "Pertentangan Antara Nabi dan Golongan Oposisi di Madinah" dalam : Pandangan Barat Terhadap Islam Lama, h. 83.
} 


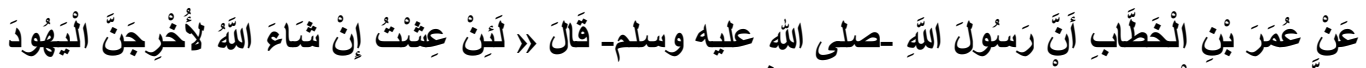

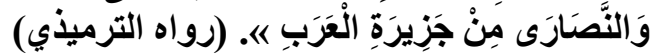

Artinya:

Dari 'Umar Ibn Khat $\}$ t $\}$ ab bahwasanya Rasulullah saw. bersabda: Seandainya saya masih hidup maka Insya Allah saya akan mengusir orang Yahudi dan Nasrani dari Jazirah Arab. (HR. al-Tirmi $>z l i>$ )

Pernyataan Rasululullah saw. tersebut di atas tidak dapat dijadikan alasan bahwa memang Rasulullah sejak awal sudah berencana untuk mengusir orang Yahudi dan Nasrani dari jazirah Arab. Hal ini terbukti bahwa ia banyak menjalin kerja sama terhadap mereka sebagaimana disebutkan dalam beberapa hadis sebagai berikut :

1) Hadis berbisnis dengan Yahudi. Rasulullah saw. melakukan kerja sama dengan penduduk Khaibar yang beragama Yahudi dalam bidang pertanian sebagaimana disebutkan dalam hadis sebagai berikut :

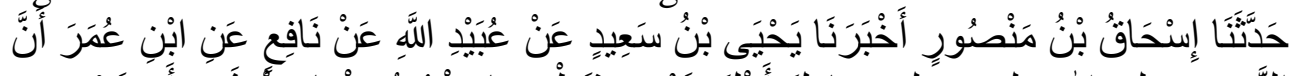

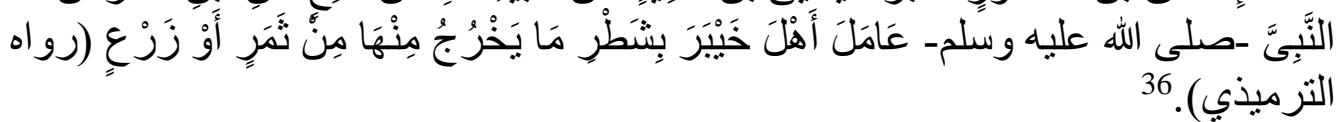

Artinya :

Telah menceritakan kepada kami Ish $\} \mathrm{a}>\mathrm{q}$ bin Mans $\} \mathrm{u}>\mathrm{r}$, telah memberitakan kepada kami $\mathrm{Yah}\} \mathrm{ya}>$ bin $\mathrm{Sa}$ ' $\mathrm{i}>\mathrm{d}$ dari 'Ubaidilla $>\mathrm{h}$ dari $\mathrm{Na}>\mathrm{fi}$ ' dari $\mathrm{Abu}>$ 'Umar bahwasanya Nabi saw. mempekerjakan penduduk Khaibar (yang beragama Yahudi) dan mendapatkan seperdua dari hasil pertaniannya (HR al-Tirmi $>\mathrm{zi}>$ ).

Perilaku Rasulullah saw. dalam melakukan interaksi dengan orang yang bukan beragama Islam dalam masalah ekonomi seperti yang disebutkan di atas, juga didukung oleh hadis yang lain sebagai berikut:

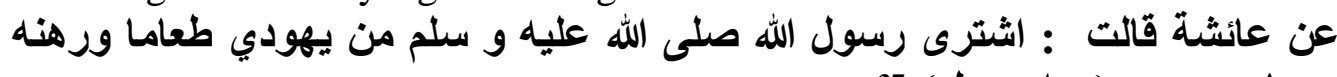

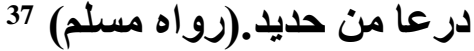

Artinya:

Dari Aisyah berkata: Bahwasanya Rasulullah saw. membeli makanan dari seorang Yahudi dengan menggadaikan baju besinya dalam waktu tertentu. (HR. Muslim).

2) Hadis tentang Pembantu Rasulullah adalah seorang Yahudi sebagaimana disebutkan dalam sebuah hadis yang berbunyi:

${ }^{36} \mathrm{Abu}>$ ' $\left.\mathrm{I}<\mathrm{sa}>\mathrm{Muh}\right\}$ ammad Ibn ' $\mathrm{I}<\mathrm{sa}>\mathrm{Ibn} \mathrm{S} \mid$ aurah, Sunan al-Tirmiz $\backslash i>$, Juz. V, h. 404.

${ }^{37} \mathrm{Ima}>\mathrm{m}$ Abu $\left.>\mathrm{H}\right\}$ usain Muslim Ibn H\{ajja>j al-Qusyairi>, S\{ah\}i>h\} Muslim, Juz. III. h. 1226. 


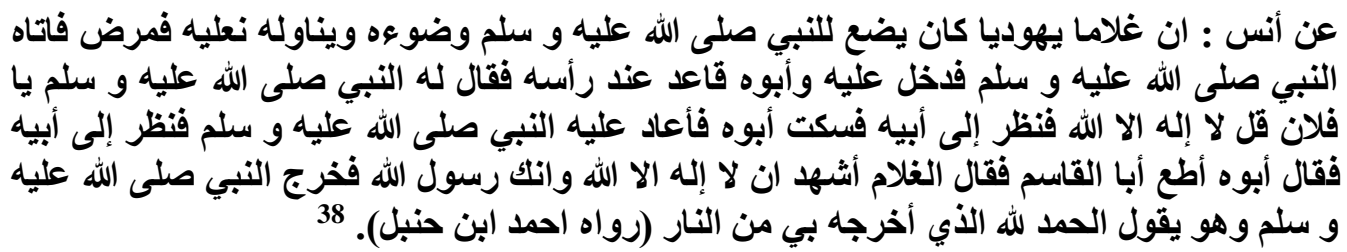

Artinya :

Dari Anas : Bahwasanya seorang pemuda menjadi pembantu Rasullullah dalam menyiapkan wudhu dan sendalnya, lalu ia sakit maka Rasulullah mendatanginya lalu masuk kepadanya sementara bapaknya duduk di dekat kepalanya. Lalu Nabi bersabda wahai Fulan katakanla: "La> Ila>ha Illa> Alla $>h$ ” Lalu pemuda itu memandang bapknya, maka bapaknya terdiam, lalu Rasulllah saw. kembali mengulangi sambil menoleh kepada bapaknya. Lalu bapaknya berkata: Ikutilah $\mathrm{Abu}>\mathrm{Qa}>\operatorname{sim}$ (Rasulullah saw.) lalu pemuda itu berkata" Saya bersaksi bahwa tidak ada Tuhan selain Allah dan Engkau utusan Allah. Lalu Rasulullah keluar dan mengucapkan: "Segala puji bagi Allah yang telah menyelamatkannya dari api neraka dengan perantaraanku." (HR Ahmad Ibn Hanbal).

Maksud hadis ini adalah bahwa Rasulullah saw. memiliki pelayan/pembantu dari orang Yahudi menunjukkan bahwa kebolehan mempekerjakan non-muslim, sama saja $A$ hl- al-kita $>b$ atau orang musyrik. Hadis ini juga menunjukkan bahwa boleh mempekerjakan anak-anak yang penting diperlakukan dengan baik dan sesuai dengan kemampuannya. Buktinya adalah bahwasanya Nabi saw. memperlakukan dengan baik anak tersebut dan ketika sakit maka Rasulullah saw. menjenguknya dan mengajaknya masuk Islam dan ternyata berhasil sebelum ajal menjemputnya. ${ }^{39}$

Pertanyaannya adalah kenapa Rasulullah saw. mengangkat pembantu atau pelayan dari orang Yahudi ?. Apakah tidak ada orang orang Islam yang mau menjadi pembantunya?. Tentu tidaklah demikian karena menurut riwayat bahwa banyak dari beberapa sahabat yang pernah berkhidmat pada keluarga Rasulullah saw.

3) Larangan menzalimi non-muslim. Sebagaimana sabda Rasulullah saw. yang berbunyi:

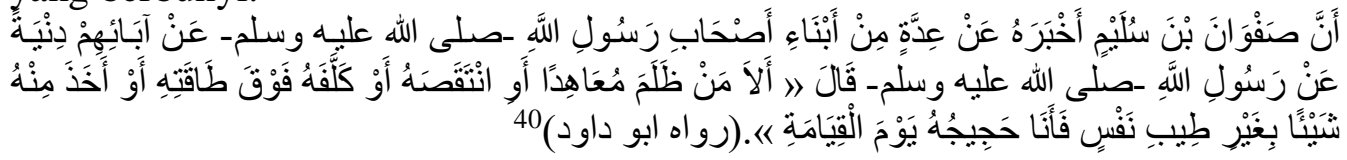

Artinya :

\footnotetext{
${ }^{38} \mathrm{Ima}>\mathrm{m}$ Ah $\} \operatorname{mad}$ Ibn $\mathrm{H}\{$ anbal, Musnad Ima>m Ah\}mad Ibn H\{anbal, Juz. III, h. 227.

${ }^{39} \mathrm{Ima}>\mathrm{m}$ al-H $\{\mathrm{a}>\mathrm{fiz}\}$ Ah $\} \operatorname{mad} \mathrm{Ibn}$ 'Ali> Ibn $\mathrm{H}\{$ ajar al-'Asqalla>ni , Fath\} al-Ba>ri> Fi> Syarh\} Sah\}i>h\} al-Bukha>ri>, Juz. III. h. 320.

${ }^{40} \mathrm{Ima}>\mathrm{m}$ Abu $>\mathrm{Da}>\mathrm{u}>\mathrm{d}$ Sulaima $>\mathrm{n}$ Ibn al-Asy'as al-Sijista>ni>, Sunan Abu>Da>ud Juz. III. h. 168 .
} 
Bahwasanya S $\{$ afwan bin Sulaim telah memberitakan kepadanya dari beberapa putra sahabat dari bapak-bapak mereka dari Rasulullah saw. bersabda: Ingatlah bahwasanya barangsiapa yang menzalimi kafir mu'ahid, mengurangi haknya, membebani di luar batas kemampuannya, atau mengambil hak miliknya tanpa perkenan darinya maka akulah yang akan menjadi musuhnya di hari kiamat (HR Abu $>$ Da $>$ u $>d$ ).

Maksud dari hadis ini adalah bahwasanya Rasulullah saw. mengingatkan kepada umatnya tidak mengurangi hak, tidak membebani seseorang di luar dari kemampuannya (dalam hal jizyah dan kharaj). Maksudnya adalah mengambil jizyah yang tidak diwajibkan kepadanya. Barang siapa yang diperlakukan demikian maka Nabi saw. yang akan membela, melindungi dan bahkan orang melakukan penindasan akan menjadi musuh Nabi. ${ }^{41}$

Di samping hadis-hadis tersebut di atas, masih banyak bukti-bukti lain yang menunjukkan bahwa Rasulullah saw. melakukan hubungan yang baik terhadap oposisi yang ada di Madinah seperti menghormati tetangga, menghormati jenazah dan lain-lain.

Berdasakan hal ini maka sesungguhnya orang Yahudi tidak menerima Muhammad saw. menjadi pemimpin di Madinah bukan karena sentimen keagamaan, akan tetapi juga tidak bisa dilepaskan dari karasteristik orang-orang Yahudi itu sendiri sebagaimana dijelaskan dalam Alqur'an yang antara lain adalah; masih menunggu Messiah, cinta harta sehingga menghalalkan berbagai cara, suka menyuluk api peperangan, menolak kepemimpinan orang arab dan lain-lain.

\section{KESIMPULAN}

Berikut ini akan dikemukakan kesimpulan dari hasil penelitian tentang hubungan nabi dengan oposisi Madinah sebagai berikut:

Pertama, Ketika Rasulullah saw. berada di Madinah, ia tetap melakukan interaksi dengan seluruh masyarakat termasuk kaum oposisi. Bentuk- bentuk oposisi Nabi saw. di Madinah adalah oposisi Yahudi yang meliputi Bani Qainuqa, Banni Nadir dan Banu Quraizah.

Kedua, Hannah Rahman menyimpulkan bahwa Nabi saw. telah mengusir oposisi di Madinah karena berambisi untuk merebut kekuasaan dan berusaha menguasai pasar. Hal ini terbukti bahwa Nabi ketika berada di Mekah tidak dapat melakukan hal itu sehingga ia berusaha pindah ke Madinah. Berdasarkan kemampuan politik dan kecerdasannya sehingga ia dapat melakukan hal tersebut di Madinah.

Ketiga, Melalui pendekatan sosiologis maka dengan sendirinya teori yang dikembangkan oleh Hannah Rahman akan terbantahkan. Kekeliruan Hannah Rahman disebabkan karena ia berangkat dari teori yang keliru. Dalam membahas masalah ini

\footnotetext{
${ }^{41} \mathrm{Ima}>\mathrm{m}$ al-H $\{\mathrm{a}>\mathrm{fiz}\} \mathrm{Ah}\left\{\operatorname{mad} \mathrm{Ibn}{ }^{\prime} \mathrm{Ali}>\mathrm{Ibn} \mathrm{H}\{\right.$ ajar al-'Asqalla $>$ ni , Fath $\}$ al-Ba $>$ ri $>\mathrm{Fi}>$ Syarh\} S\{ah\}i>h\}al-Bukha>ri>, Juz. VIII. h. 211.
} 
Hannah Rahman memakai teori konflik Karl Marx kemudian dikembangkan oleh Vilfredo Pareto dan Lewis Coser yang mengatakan bahwa pergolakan politik dunia sebagai akibat dari pertentangan antara dua tipe individu yaitu (singa, penguasa, penindas) dan (kancil atau yang dikuasai). Hal ini didukung oleh beberapa hadis yang menunjukkan bahwa Rasulullah saw. melakukan hubungan yang baik dengan oposisi Madinah dan bahkan melindungi mereka sepanjang tidak membahayakan Islam.

\section{DAFTAR PUSTAKA}

Abdullah, Prof. Dr. M. Amin, Islamic Studies di Perguruan Tinggi: Pendekatan Integratif-Interkonektif, Cet. II, Yogyakarta: Pustaka Pelajar, 2010.

Ahmad, Prof. Dr. H. Arifuddin, Metodologi Pemahaman Hadis: Kajian Ma'a $>n i$ al$H a>d i s$, Cet. II; Makassar: Alauddin Universty Press, 2013.

Departemen Agama RI, Al-Qur'an dan Terjemahnya, Madinah al-Munawwarah: Mujamma' al-Malik Lit-Tiba>'ah al-Mushaf al-Syari>f, 1993.

Esaak, Farid, Qur'an Liberation and Pluralism, Oxford: One World, 1997.

al-Ghaza>li, Muhammad, Fiqh U- Seerah : Understanding the Life of Prophet Muhammad, terj. Kamdani, Sejarah Perjalanan Hidup Muhammmad, Cet. IV; Yogyakarta: 2005.

Hasan, Muhammmad Khalifah, Ta>ri>kh Ad-Diya>nah Al-Yahu>diyah, terj. Abdul Shomad dan Faisal Saleh, Sejarah Agama Yahudi, Cet. I, Jakarta: Pustaka AlKautsar, 2009.

Hidayat, Komaruddin, Memahami Bahasa Agama, Sebuah Kajian Hermeneutik, Jakarta: yayasan Paramadina, 1996.

----------, Menafsirkan Kehendak Tuhan, Cet. II; Jakarta: Teraju, 2004.

Howard, Roy. J., Three Faces of Hermeneutics: An Introduction to Current Teories of Understanding, diterjemahkan oleh Kusmana dan M.S. Nasrullah dengan Judul: Pengantar atas Teori-Teori Pemahaman Kontemporer. Hermeneutika: Wacana Analitik, Psikososial dan Ontologis, Cet. II; Bandung: Yayasan Nuansa Cendikia, 2001.

Lapidus, Ira. M., Sejarah Sosial Umat Islam, terj. Ghufron A. Mas'adi, Jilid 1 dan 2.

Moleong, Lexy J., Metodologi Penelitian Kualitatif, Bandung: Remaja Rosdakarya, 2008.

Mustafa, Agus, Perlukah Negara Islam, Surabaya: PADMA Press, t.th.

Phipps, William E., Muhammad and Jesus: A Comparison of the Prophets and Their Teachings, terj. Ilyas Hasan dengan judul, Muhammad \& Isa: Telaah Kritis atas Risalah dan Sosoknya, cet. V; Jakarta: Mizan, 2001.

al-Qusyairi>, Ima>m Abu> Husain Muslim Ibn Hajja>j, S\{ahi>h Muslim, Juz. III Cet.I; Kairo: Da>r al-Hadi >sl, 1991.

Rahman, Hannah (Haifa), "Pertentangan Antara Nabi dan Golongan Oposisi di Madinah” dalam : Pandangan Barat Terhadap Islam Lama, Jakarta: INIS, 2010. 
Robertson, Roland, Agama dalam Analisa dan Interpretasi Sosiologis, Jakarta: Rajawali Pers, 1988.

al-Sijistani>, Imam Abu> Da>ud Sulaima>n Ibn al-Asy'as, Sunan Abu>Da>ud, Juz. III. Beirut : Da>r Al-Fikr, t.th.

Suprayogo, Prof. Dr. Imam, dan Drs. Tabroni M.Si., Metododlogi Penelitian Sosial Agama, cet. 2; Bandung: PT Remaja Rosdakarya, 2003.

Sumaryono, E., Hermeneutik Sebuah Metode Filsafat, Yogyakarta: Kanisisus, 1999.

Suriasumantri, Jujun, "Penelitian Ilmiah, Kefilsafatan dan Keagamaan: Mencari

Paradigma Kebersamaan", dalam Mastuhu dkk, Tradisi Penelitian Agama Islam, Bandung: Nuansa, 1998 